Testy Psychologiczne w Praktyce i Badaniach, 2019, Numer specjalny, 2, 7-19 ISSN: 24499072

BARTOSZ ZALEWSKI*

Uniwersytet SWPS; Ogólnopolska Sekcja Diagnozy Psychologicznej Polskiego Towarzystwa Psychologicznego

ALEKSANDRA KAMIŃSKA

Centralny Szpital Kliniczny MSW w Warszawie; Ogólnopolska Sekcja Diagnozy

Psychologicznej Polskiego Towarzystwa Psychologicznego

\title{
Diagnoza osób ubiegających się o nadanie statusu uchodźcy w Polsce - omówienie nowelizacji
}

\begin{abstract}
Od czasu powstania pierwszych standardów procesu diagnozowania uchodźców zaszły w tym obszarze istotne zmiany, związane z wprowadzeniem nowych regulacji (standardy ogólne, nowe procedury identyfikacji uchodźców). W tekście opisana jest nowelizacja dokumentu - powody i konsekwencje zmiany jego statusu ze Standardów na Wskazówki, odniesienie do Standardów ogólnych, wnioski wynikające $\mathrm{z}$ recepcji pierwszego dokumentu $\mathrm{W}$ środowisku oraz opis wprowadzonych zmian.

Since the first standards of the refugee diagnosis process were established, significant changes have taken place in this area, related to the introduction of new regulations (general standards, new procedures for identification of refugees). The text describes the amendment of the document - reasons and consequences of changing its status from Standards to Guidelines, reference to General Standards, conclusions resulting from the reception of the first document in the environment and a description of the changes.
\end{abstract}

Dokument pt. „Wskazówki realizacji standardów ogólnych prowadzenia procesu diagnostycznego w sprawach osób ubiegających się o nadanie statusu uchodźcy w Polsce" został uchwalony przez Zarząd Ogólnopolskiej Sekcji Diagnozy Psychologicznej PTP w dniu 13 września 2015 roku. Jest on znowelizowaną wersją poprzedniego dokumentu o tytule „Standardy postępowania diagnostycznego w sprawach osób ubiegających się o nadanie statusu uchodźcy w Polsce" (Zalewski i Kamińska, 2015). Oba dokumenty przygotował Zespół Roboczy ds. Diagnozowania Uchodźców, który ukonstytuował się 28 października 2013. Obecną nowelizację przygotowano $\mathrm{z}$ trzech głównych powodów: (1) powstania standardów ogólnych i dostosowania do nich niniejszych wskazówek, (2) wdrożenia nowej procedury identyfikacji uchodźców w Polsce oraz (3) recepcji dotychczasowych standardów w środowisku psychologów. Poniżej opisano kolejno te zmiany.

Warto podkreślić, że dokumenty opisujące standardy oraz wskazówki postępowania diagnostycznego są z założenia dokumentami otwartymi, podlegającymi stopniowym modyfikacjom i uzupełnieniom. Otwarta formuła umożliwia stymulowanie dobrych praktyk

* Adres do korespondencji: Bartosz Zalewski, Katedra Diagnozy Psychologicznej Wydział Psychologii SWPS w Warszawie bzalewsk@swps.edu.pl 
w zmieniającej się rzeczywistości, m.in. prawnej, rozwoju narzędzi badawczych, kontekstu badań. Dzieje się to poprzez refleksję nad nowymi zjawiskami oraz wynikające z niej wskazania praktyczne. Proces ten sprzyja profesjonalizacji zawodu (Filipiak i in, 2015), a opisywana nowelizacja jest ucieleśnieniem tej idei.

\section{Zmiana Standardów na Wskazówki}

W dniu 21 czerwca 2014 roku, jedynie na dwa tygodnie przed uchwaleniem standardów dla diagnozowania uchodźców (1 lipca 2014 roku) opublikowano dokument nadrzędny pt. „Standardy diagnozy psychologicznej” (Paluchowski, Tarnowska, Filipiak i Zalewski, 2015). Prace nad oboma dokumentami trwały równolegle, choć wersja odnosząca się do uchodźców powstawała nieco wcześniej. Oba tworzono w innym kontekście praktyki psychologicznej (ogólna vs specjalistyczna) i przyjęto w nich odmienne założenia dotyczące struktury, szczegółowości omawiania zagadnień jak i akcentowania różnych treści. Dokument dotyczący uchodźców skierowany był do niewielkiej grupy wyspecjalizowanych psychologów, pracujących w kontekście polskiej procedury identyfikacji uchodźców. Zawierał on bardziej szczegółowe wskazówki niż dokument ogólny. Znalazło to swoje odbicie $\mathrm{w}$ dodatkowych, drobiazgowych rekomendacjach dotyczących m.in. umeblowania miejsca pracy psychologa, niezwykle istotnych w tym kontekście (omówienie w: Zalewski i Kamińska, 2015).

Po opublikowaniu Standardów ogólnych rozpoczęto prace nad dostosowaniem do nich niniejszego dokumentu. Zmieniono jego nazwę i status ze „Standardów” na „Wskazówki realizacji standardów ogólnych...”, dzięki czemu uzyskał on właściwą rangę oraz został dostosowany do innych dokumentów szczegółowych (opisywanych w tym numerze). Standardy tworzą generalny opis zasad postępowania psychologa podczas prowadzenia procesu diagnozy, zaś dokumenty opisujące wskazówki odnoszą je do konkretnych, specyficznych obszarów praktyki. Ostatecznie w nowelizacji zachowano strukturę z pierwszej wersji dokumentu, tj. zamiast pięciu działów w Standardach zachowano strukturę ciągu 22 punktów oraz czterech rekomendacji. Skoncentrowano się na zmianach w treści wskazówek. Zmieniono kolejność punktacji, dodano punkty:

- nr 9 - wstępna rozmowa informacyjna z psychologiem,

- nr 12 - informowanie o celu badania i efektach w kontekście rozbudowanych regulacji kontraktowania badań psychologicznych w standardach ogólnych

- nr 22 - uporządkowanie kwestii własności stosowanych narzędzi diagnostycznych, ze wskazaniem, że właścicielem jest osoba lub instytucja, która opłaciła ich zakup i która ponosi odpowiedzialność za ich właściwe przechowywanie. 
Ponadto w części „Rekomendacje” dotyczących miejsca pracy psychologa dodano konieczność przechowywania dokumentacji w miejscach zabezpieczonych przed dostępem osób trzecich. Dodano odnośniki do Standardów ogólnych, tworząc połączenia pomiędzy oboma dokumentami.

\section{Nowe procedury dotyczące uchodźców w Polsce}

Urząd ds. Cudzoziemców wdrożył w 2015 roku nową procedurę identyfikacji osób wnioskujących o nadanie statusu uchodźcy w Polsce, zawierającą odniesienia do diagnostyki psychologicznej (Filipiak i in., 2014). Stworzyło to nowy kontekst prawny i praktyczny działania psychologów, do którego dostosowano treść Wskazówek. Znacznie uproszczono opis zasad budowania raportu końcowego z badań psychologicznych, wprowadzając klarowne rekomendacje odnośnie trybu postępowania wobec osób wymagających szczególnego traktowania. Obecnie znajduje się w nim jasne wskazanie określające czy osoba może uczestniczyć w przesłuchaniu, czy też powinno być ono odroczone (np. ze względu na objawy psychopatologiczne, mogące utrudniać relacjonowania zdarzeń przez osobę) oraz czy osobie podczas przesłuchania powinien towarzyszyć psycholog, dzięki czemu psycholodzy zostali aktywnie włączeni do decydowania o warunkach przesłuchania. Do raportu wprowadzono także m.in. rekomendacje dotyczące płci osób uczestniczących w przesłuchaniu (urzędnik, tłumacz, psycholog), co jest istotne ze względu na treść przesłuchań, gdzie zbiera się szczegółowe dane dotyczące wydarzeń traumatyzujących, jakich mogła doświadczyć osoba (w tym m.in. gwałtów), a także ze względu na kontekst kulturowy osoby przesłuchiwanej (np. dotyczący możliwości rozmawiania przez kobiety z nieznanym mężczyznami, co $\mathrm{w}$ niektórych kulturach pochodzenia osób podlegających procedurze identyfikacyjnej nie jest akceptowane). Usunięto natomiast konieczność tworzenia dodatkowych broszur dla urzędników, objaśniających zawartość raportu psychologa, ponieważ obecnie jest on znacznie prostszy i bardziej czytelny. Z perspektywy czasu warto wskazać zasadność wprowadzonych zmian, jako że obecnie raport ten stał się standardowym narzędziem stosowanym w komunikacji pomiędzy psychologami i pracownikami Urzędu ds. Cudzoziemców.

Od czasu opublikowania pierwszej wersji standardów diagnozowania uchodźców, zauważono szereg błędów występujących $\mathrm{w}$ raportach $\mathrm{z}$ badań, rekomendacjach oraz działaniu psychologów w kontekście szerszej procedury identyfikacji. Najczęściej psycholodzy wykraczali w nich poza swoje kompetencje, np. wykonując prace śledczych, dokonując diagnostyki medycznej czy podejmując próby terapii traumy w ramach procedury identyfikacyjnej (por. Kamińska i Zalewski, 2017). W tym kontekście w rekomendacjach 
dodano konieczność odbycia przez psychologów szkoleń z zakresu systemu identyfikacji i wsparcia osób ubiegających się o nadanie statusu uchodźcy w Polsce i Europie. Dookreślono także specyficzne elementy wykształcenia psychologa, umożliwiające pracę z uchodźcami w tym systemie. Psycholodzy powinni być świadomi ograniczeń swoich działań oraz tego, w jaki sposób ich raporty będą wykorzystywane przez innych uczestników procedury. Opisano także zasady uzyskiwania świadomej zgody na udział w badaniach psychologicznych, odnosząc je do Standardów ogólnych (pkt. 1.3, 1.4, 1.7 i 1.8).

\section{Recepcja standardów w środowisku}

Trzeci rodzaj zmian, jakie wprowadzono, wynika z dotychczasowej recepcji standardów w środowisku psychologów pracujących z uchodźcami. Komentarze praktyków spowodowały szczególne podkreślenie faktu, że psycholog nie podejmuje się wykrywania, dochodzenia ani orzekania o tym, czy osoba realnie była ofiarą wydarzeń o charakterze traumatycznym. Psycholog nie posiada narzędzi, pozwalających na określanie takich faktów, jest to zadanie przeznaczone dla śledczych. $Z$ perspektywy czasu widać słuszność takiej zmiany, ponieważ opinie psychologów przestały być wykorzystywane przez urzędników Urzędu ds. Cudzoziemców jako dowody na to, że realne wydarzenia z przeszłości naprawdę miały miejsce. Wcześniej zauważono, że jeśli w opinii psychologa nie wskazano, że osoba doświadczyła konkretnych wydarzeń traumatycznych, wówczas opinie traktowane bywały jako dowód na brak takich wydarzeń, co sprzyjało odrzuceniu wniosku tej osoby o ochronę. Tworzyło to niebezpieczną sytuację, $\mathrm{w}$ której błędy metodologiczne, związane $\mathrm{z}$ budowaniem opinii, włączane były $\mathrm{w}$ szerszy aspekt społeczny i przyczyniały się do tworzenia fałszywych wniosków o statusie dowodu. W nowelizacji uporządkowano opis informacji, jakie powinien zawierać raport psychologa, usunięto informację o potencjalnym doświadczonym typie przemocy, mocy danych z jaką diagnozowano tą przemoc oraz szczegółowy opis przemocy i jej kontekstu. Innymi słowy konsekwentnie usunięto fragmenty, w których psycholog miałby diagnozować, czy wystąpiły konkretne i realne sytuacje przemocy wobec osoby diagnozowanej. Obecnie psycholog jedynie rekomenduje czy osoba może być przesłuchiwana w danym momencie ze względu na jej stan zdrowia psychicznego (w tym aktualne symptomy PTSD), nie wypowiada się natomiast o prawdziwości relacjonowanych wydarzeń.

W rekomendacjach dodatkowych zmieniono wskazówki dotyczące znajomości języków obcych przez psychologów: podkreślono wagę znajomości języka kraju, z którego pochodzi większość osób w procedurze, nie zaś wyłącznie języków angielskiego i rosyjskiego, uelastyczniając te rekomendacje. Utrzymano w mocy rekomendacje, dotyczące pracy 
tłumacza towarzyszącego psychologowi podczas kontaktów z cudzoziemcami (szerzej opisane w: Wądołowska, 2014). W odpowiedzi na zapotrzebowanie środowiska sformułowano także rekomendacje dotyczące stanowiska krajowego koordynatora psychologów pracujących w ośrodkach dla cudzoziemców (do dzisiaj jednak takie stanowisko nie powstało).

\section{Literatura cytowana}

Filipiak, M., Kamińska, A., Kamiński, K., Kownacka, E. (2014). Procedura identyfikacji osób o szczególnych potrzebach wnioskujących o nadanie statusu uchodźcy w Polsce perspektywa psychologiczna. Pobrano dnia 01.05.2019 r. ze strony:

https://diagnozowanieuchodzcow.wordpress.com/.

Filipiak, M., Tarnowska, M., Zalewski, B., Paluchowski, J. W. (2015). O systemie kształcenia ustawicznego psychologów diagnostów w Polsce. Roczniki Psychologiczne, 18(2), 157-184.

Kamińska, A., Zalewski, B. (2017). Zniekształcenia i btędy w procesie diagnozowania cudzoziemców - refleksje w kontekście wskazówek realizacji standardów prowadzenia procesu diagnozy. Wystąpienie podczas I Konferencja z cyklu Diagnoza w praktyce psychologicznej pt. „Współczesna praktyka diagnostyczna - osiągnięcia i wyzwania”, 1617.03.2017, Uniwersytet SWPS, Warszawa.

Paluchowski, J. W., Tarnowska, M., Filipiak, M., Zalewski, B. (2015). Standardy diagnozy psychologicznej. [W:] M. Filipiak, W. J. Paluchowski, B. Zalewski i M. Tarnowska (red.), Diagnoza psychologiczna: kompetencje i standardy. Wybrane zagadnienia (57-93). Pracownia Testów Psychologicznych PTP.

Wądołowska, K. (2014). Praca z tłumaczem $w$ terapii i diagnozie psychologicznej. Specyfika pracy oraz zalecenia dla psychologów wspótpracujacych z thumaczami na rzecz cudzoziemców. Pobrano dnia 01.05.2019 r. ze strony:

https://sekcjadiagnozy.wordpress.com/standardy-diagnostyczne/zespol-roboczy-dsdiagnozowania-uchodzcow/. Praca niepublikowana.

Zalewski, B., Kamińska, A. (2015). Diagnoza osób starających się o otrzymanie statusu uchodźcy w Polsce. [W:] M. Filipiak, W. J. Paluchowski, B. Zalewski i M. Tarnowska (red.), Diagnoza psychologiczna: kompetencje i standardy. Wybrane zagadnienia (321-342). Pracownia Testów Psychologicznych PTP. 
Załącznik

\section{Wskazówki realizacji standardów ogólnych prowadzenia procesu diagnostycznego w sprawach osób ubiegających się o nadanie statusu uchodźcy w Polsce}

1. Psycholog rozpoznaje czy posiada kompetencje konieczne do zaplanowania i przeprowadzenia procesu diagnostycznego w wymienionym wyżej obszarze. (por. pkt. 1.4 standardów ogólnych)

2. Psycholog zachowuje pozycję niezależną od zleceniodawcy, w tym przypadku odpowiednich urzędów, instytucji oraz ich przedstawicieli włączonych w postępowanie. (por. pkt. 1.6 standardów ogólnych)

3. Psycholog ponosi odpowiedzialność za całość procesu diagnostycznego. (por GAP, General Principle no 1)

4. Proces diagnozy psychologicznej prowadzony jest przez psychologa, a nie inne osoby trzecie.

Komentarz: Psycholog powinien aktywnie dążyć do tego, aby inne osoby (w tym urzędnicy) nie wykonywały zadań psychologicznych, tzn. przygotowania i prowadzenia wywiadów obejmujących diagnostykę psychologiczną, używania narzędzi, formułowania wniosków diagnostycznych. Zadaniem psychologa jest ochrona uczestników procesu diagnostycznego przed byciem diagnozowanym przez osoby niekompetentne $\mathrm{w}$ tym zakresie.

5. Psycholog poddaje swoją pracę superwizji, także koleżeńskiej.

Komentarz: Psycholog aktywnie dba o to, aby zapewnić sobie możliwość konsultowania prowadzonych przez siebie procesów diagnostycznych. Psycholog dokonuje diagnostyki samodzielnie lub wraz z innymi psychologami, zaangażowanymi w dane postępowanie. (por. pkt. 1.5.1 oraz 1.6 standardów ogólnych)

6. Psycholog regularnie podnosi swoje kompetencje poprzez dzialania rekomendowane w dokumentach EuroPsy oraz standardach prowadzenia procesów diagnostycznych Polskiego Towarzystwa Psychologicznego, m. in. poprzez czytanie literatury fachowej, uczestnictwo w szkoleniach oraz konferencjach naukowych.

7. Psycholog współpracuje $z$ pracownikami medycznymi (lekarze i pielęgniarki) i socjalnymi na równych prawach, wykonując samodzielne działania związane $z$ jego profesjonalnymi kompetencjami. (por. pkt. 1.2 standardów ogólnych) 
8. Psycholog jest kompetentny, w tym ${ }^{1}$ (por. pkt. 1.4 standardów ogólnych):

- podejmuje działania oparte o posiadane przez siebie kompetencje, rozumiane zgodnie $\mathrm{z}$ modelem kompetencji European Federation of Psychologists Associations (Roe, 2002);

- podejmuje działania oparte o wiedzę naukową, zgodnie z ideami Evidence Based Assessment (EBA, APA, 2006);

- podejmuje działania zgodne $\mathrm{z}$ zasadami etycznego postępowania, w tym szczególnie (pkt. 1.3 standardów ogólnych oraz GAP General Principle nr 3):

- dba o dobrostan uczestników badań,

- zawiera kontrakt na badania (pkt. 1.7 standardów ogólnych),

- używa narzędzi diagnostycznych o sprawdzonych właściwościach psychometrycznych,

- udziela informacji zwrotnych uczestnikowi badania w oparciu o podejście współpracujące z uczestnikiem/czką badań (GAP, Fernansez-Ballesterow i in, 2001; Kodeks Etyczny PTP; Collaborative Approach, Berschoff, 1995);

- traktuje uczestników badań podmiotowo z wszelkimi konsekwencjami tego podejścia, (GAP, Fernansez-Ballesterow i in, 2001);

- posiada kompetencje: etyczne, relacyjne, komunikacyjne i kulturowe (Krishmamurthy i in, 2004; Lunt, 2001; Roe, 2002).

9. Każda osoba, składająca wniosek o ochronę międzynarodową w Polsce, powinna przechodzić wstępną rozmowę $\mathrm{z}$ psychologiem. Celem rozmowy jest przekazanie informacji na temat roli psychologa $w$ ogóle oraz roli psychologa w kontekście procedury postępowania o nadanie ochrony międzynarodowej.

Komentarz: Rozmowa informacyjna powinna być przeprowadzana w ośrodkach recepcyjnych możliwe jak najwcześniej. Dopuszcza się przeprowadzenie takiej rozmowy w ośrodkach pobytowych, zaraz po zakwaterowaniu cudzoziemców. Celem rozmowy nie jest diagnostyka psychologiczna (diagnostyka może być prowadzona na późniejszych etapach), a jedynie informacja. Celem takiego działania jest nawiązanie kontaktu z cudzoziemcami, przekazanie im rzetelnych informacji na temat sposobu pracy psychologów oraz ich roli.

10. Każdy cudzoziemiec powinien przechodzić badania psychologiczne, których celem jest określenie, $w$ jakim trybie wobec tej osoby powinno być prowadzone postępowanie o nadanie ochrony międzynarodowej (tryb standardowy lub szczególny rozumiany wg odpowiednich przepisów).

${ }^{1}$ Opis poniższych kompetencji w literaturze polskiej znajduje się w: StemplewskaŻakowicz, K. (2009). Diagnoza psychologiczna. Diagnozowanie jako kompetencja profesjonalna. Gdańsk: GWP. 
Komentarz: Diagnostyka dotycząca trybu postępowania powinna być przeprowadzana wyłącznie w ośrodku pobytowym najwcześniej dwa tygodnie od zakwaterowania. Wskazówka ta dotyczy także osób, które po przyjeździe do Polski zakwaterowane są na zasadzie świadczeń prywatnych. Postuluje się zrezygnowanie z badań na wcześniejszych etapach ze względu na:

- często bardzo krótki pobyt w ośrodku recepcyjnym i szybkie odsyłanie do ośrodka pobytowego;

- niemiarodajne wyniki badań (według wskazań fińskiego urzędu imigracyjnego doświadczenia związane z traumą pojawiają się w dalszych badaniach wraz z upływem czasu, natomiast badania prowadzone w pierwszych dniach pobytu są niemiarodajne pod tym względem);

- symptomy związane ze stresem podróży, migracji, przechodzenia przez granicę są pierwszoplanowe, dopiero ich słabnięcie „odsłania” inne zaburzenia lub trudności.

11. Rozmowy informacyjne oraz diagnostykę prowadzi jeden i ten sam psycholog wobec jednej osoby. Intencją takiego rozwiązania jest zmniejszenie niestabilności otoczenia, w jakim przebywa osoba.

12. Przed rozpoczęciem badania każda osoba powinna zostać poinformowana o celu badania oraz jego efekcie, czyli wystawieniu opinii przekazywanej do Urzędu ds. Cudzoziemców. Badany ma prawo odmówić udziału w badaniu, a jedyną konsekwencją odmowy będzie brak możliwości rozpoznania przez psychologa wymaganego trybu postępowania.

13. Psycholog podejmuje działania na rzecz dobrostanu osoby przebywającej w ośrodku pobytowym, w tym (por. GAP, General Principle nr 3, 4 oraz 5):

- sporządza rekomendacje dotyczące podjęcia interwencji wobec doświadczanego przez osobę aktualnego kryzysu lub innych symptomów stresu;

- składa zapotrzebowania na zakup narzędzi do badania symptomów stresu oraz objawów psychopatologicznych;

- przekazuje pracownikom medycznym zalecenia dotyczące uczestnika badań (np. wskazania dotyczące dalszych konsultacji internistycznych i/lub psychiatrycznych);

- formułuje rekomendacje dotyczące zakwaterowania osób w ośrodku w kontekście ich dobrostanu psychicznego, których celem jest przeciwdziałanie kwaterowaniu w jednym pokoju osób przeżywających podobny rodzaj kryzysu psychologicznego, co przeciwdziała amplifikacji symptomów; ponadto osoba nie doświadczająca kryzysu może stanowi

- rodzaj opiekuna, informującego personel medyczny o pogorszeniu się stanu osoby dzielącej z nim pokój.

- wobec osób wymagających interwencji kryzysowych psycholog opracowuje plan 
interwencji i je przeprowadza.

14. Psycholog przeprowadza diagnostykę aktualnie pojawiających się symptomów posttraumatycznych. Wydana opinia może być dowodem w sprawie postępowania o nadanie ochrony międzynarodowej. (por. pkt. 2.2 i 4.1 standardów ogólnych oraz pkt. 1.2.1 i 1.4.1-1.4.2 modelu GAP).Psycholog używa zróżnicowanych metod diagnostycznych (por. pkt. 2.4.1-2.4.3 standardów ogólnych oraz pkt. 1.2.2-1.2.2 modelu GAP), w tym:

- wywiadu psychologicznego;

- obserwacji;

- narzędzi testowych i kwestionariuszowych (por. pkt. 4.1.1 standardów ogólnych oraz pkt. 1.3.1-1.3.3 modelu GAP);

- dostępnych w wersji języka ojczystego uczestnika badania;

- o ile to możliwe zaadaptowanych kulturowo dla kręgu kultury ojczystej dla uczestnika badania.

15. Psycholog dokłada starań, aby minimalizować ilość badań, podczas których uczestnicy opowiadają o przeżytych wydarzeniach traumatycznych. Badanie obejmujące szczególowy opis wydarzeń traumatycznych poleca się przeprowadzać nie więcej niż jeden raz. Badanie takie przeprowadzać może wylącznie osoba kompetentna, czyli psycholog posiadający odpowiednią wiedzę i umiejętności. Takie postępowanie minimalizuje dyskomfort uczestników postępowania diagnostycznego. (por. GAP General Principle nr 3 i nr 4)

16. Psycholog nie podejmuje się wykrywania, dochodzenia ani orzekania o tym czy osoba doświadczyła wydarzenia traumatycznego, ponieważ nie posiada ku temu narzędzi (por. pkt. 2.1, 2.2 i 2.4 standardów ogólnych). Psycholog nie poszukuje prawdy obiektywnej, lecz kierowany wiedzą psychologiczną poszukuje połączeń pomiędzy elementami zachowań i wypowiedzi klienta - takich jak emocje, wartości, doświadczenia, symptomy oraz inne. Psycholog nie podejmuje się orzekania, czy uczestnik badania mówi prawdę.

Zakres diagnostyki psychologicznej w danym obszarze obejmuje diagnozę reakcji kryzysowych na wydarzenia traumatyczne. Psycholog podejmuje się zdiagnozowania wystąpienia u uczestnika badań syndromów psychologicznych opisanych w odpowiednim systemie klasyfikacji zaburzeń psychicznych (ICD-10).

17. W procedurze postępowania o nadanie ochrony międzynarodowej psycholog aktywnie dziala tak, aby prowadzić elementy procedury związane $z$ diagnostyką psychologiczną oraz dbaniem o dobrostan uczestników badań (por. GAP General Principle no 3): prowadzi diagnostykę symptomów post-traumatycznych.

Psycholog działa aktywnie w tym kierunku, by osoby niekompetentne nie prowadziły działań z zakresu zbierania i analizy danych dotyczącej diagnozy psychologicznej. 
18. Osoby, u których nie zdiagnozowano kryzysu, nie muszą być objęte ochronnymi dzialaniami psychologa podczas uczestnictwa $w$ procedurze postępowania $o$ nadanie ochrony międzynarodowej.

19. Psycholog sporządza raport ze swoich działań na rzecz zleceniodawcy prowadzącego postępowanie o nadanie ochrony międzynarodowej (por. pkt. 5.1-5.5 standardów ogólnych oraz model GAP pkt. 2.2.1-2.2.2)

Sporządzając opinię psycholog pozostaje bezstronny, tzn. nie działa na korzyść uczestnika badań (nie buduje intencjonalnie opinii zwiększającej prawdopodobieństwo uzyskania przez osobę statusu uchodźcy, niezależnie od doświadczenia przez nią przemocy) ani na korzyść zleceniodawcy (nie buduje intencjonalnie opinii zmniejszającą to prawdopodobieństwo). Psycholog nie ingeruje $\mathrm{W}$ proces podejmowania decyzji o nadaniu ochrony międzynarodowej. Rolą psychologa jest rozpoznanie i raportowanie symptomów doświadczenia przemocy i danych związanych $\mathrm{z}$ doświadczeniami traumatycznymi wraz z oceną mocy zebranych danych.

Raport psychologiczny wystawiany na zlecenie Urzędu mający na celu określenie trybu postępowania (tryb zwykły lub tryb szczególny) powinien zawierać następujące informacje:

- stwierdzenie istnienia lub braku występowania u danej osoby objawów mogących zaburzać funkcjonowanie oraz relacjonowanie zdarzeń podczas wywiadu statusowego,

- możliwości lub braku możliwości wzięcia przez osobę udziału w wywiadzie statusowym,

- dodatkowe sugestie dotyczące wywiadu (obecność psychologa, odroczenie wywiadu)

- wskazanie niezbędnych konsultacji - lekarskich, specjalistycznych.

Opinia psychologiczna wystawiana na zlecenie Urzędu dotycząca stanu psychicznego osoby powinna zawierać następujące informacje:

- możliwości lub braku możliwości wzięcia przez osobę udziału w wywiadzie statusowym;

- opis aktualnych symptomów np. poprzez zaznaczenie na ogólnej liście symptomów;

- dodatkowe wskazówki wspierające urzędnika w prowadzeniu rozmowy z daną osobą;

- wskazanie niezbędnych konsultacji - lekarskich, specjalistycznych.

Powyższą opinię psycholog prezentuje uczestnikowi/czce badań oraz wprowadza do niej zmiany oparte o wskazania podejścia współpracującego w diagnostyce psychologicznej (collaborative approach). Zmiany te dotyczą unikania stygmatyzacji uczestnika/czki badań. Omówienie raportu jest także podstawą do uzgadniania podjęcia ewentualnych interwencji psychologicznych (por. pkt. 2.3.1 modelu GAP). 
20. Psycholog kończy swoje działania na zlecenie Urzędu (dotyczące wywiadu statusowego) wraz $z$ wystawieniem opinii dotyczącej występowania zaburzeń związanych z kryzysem psychologicznym (por. model GAP: End of the Assessment Process - kończenie procesu diagnozowania).

21. Za właściwe przechowywanie dokumentacji procesu diagnozy odpowiada osoba lub instytucja, która zatrudnia psychologa prowadzącego badanie i/lub opłaciła zakup narzędzi diagnostycznych.

Komentarz: Właściwe przechowywanie dokumentacji procesu diagnozy oznacza, że nie mają do niej dostępu osoby nieupoważnione. Dostęp do dokumentacji psychologicznej ma jedynie psycholog prowadzący diagnostykę. Raport psychologiczny może być udostępniony jedynie uczestnikowi badania oraz instytucji, na wniosek której raport został sporządzony, z zastrzeżeniem, że dostęp do raportu ma jedynie urzędnik prowadzący postępowanie o nadanie ochrony międzynarodowej. O kopię raportu może także wystąpić personel medyczny oraz psycholog pracujący w ośrodku dla cudzoziemców w którym aktualnie przebywa uczestnik badania. Arkusze narzędzi użytych w badaniach, w tym - elektroniczne, powinny być przechowywane w sposób uniemożliwiający dostęp do nich osobom nie upoważnionym, $\mathrm{w}$ tym - nie będącym psychologami zatrudnionymi/szkolącymi się $\mathrm{w}$ danej instytucji (jeśli badanie odbywało się w ramach określonej instytucji).

22. Właścicielem narzędzi diagnostycznych jest osoba lub instytucja, która opłaciła ich zakup i to ona odpowiada za ich właściwe przechowywanie. W przypadku, gdy zakupu narzędzi dokonal psycholog (np. prowadzący jednoosobową dzialalność gospodarczą), to on osobiście odpowiada za właściwe przechowywanie narzędzi diagnostycznych.

\section{Rekomendacje dodatkowe}

Rekomenduje się stworzenie krajowego koordynatora psychologów pracujących w ośrodkach dla cudzoziemców.

Należy stworzyć rekomendacje dotyczące wymagań, jakie powinien spełniać superwizor psychologów pracujących z osobami ubiegającymi się o status uchodźcy.

Raportowi opracowanemu przez psychologa na potrzeby Urzędu ds. Cudzoziemców powinien towarzyszyć krótki podręcznik (broszura) skierowanych do osób prowadzących postępowanie o nadanie ochrony międzynarodowej i wyjaśniający kwestie związane $\mathrm{z}$ działaniami oraz raportem psychologa. Podręcznik powinien opierać się na ideach Evidence Based Assessment (EBA) i powinien zwierać:

- idee, na jakich zbudowany jest raport (m.in. EBA, GAP, collaborative approach) oraz krótko zaprezentowane kompetencje konieczne do uzyskania danych diagnostycznych o wysokiej mocy; 
- argumenty naukowe uzasadniające wyłączenie urzędnika $\mathrm{z}$ fragmentu wywiadu dotyczącego szczegółów sytuacji doświadczenia przemocy i traumy;

- opis procesów poznawczych i emocjonalnych związanych z pamięciowym odtwarzaniem takich sytuacji wraz z odpowiednimi argumentami naukowymi; celem jest rozbijanie mitów dotyczących $\mathrm{m}$. in. logiki odtwarzania zdarzeń, dokładności odtwarzania zdarzeń, itp.;

- podręcznik powinien opisywać poznawcze zniekształcenia procesów podejmowania decyzji; są to najczęściej błędy myślenia charakterystyczne dla podejmowania decyzji przez ludzi, szeroko zbadane w różnych kontekstach praktycznych (np. błędy diagnostyczne lekarzy, psychiatrów i psychologów; błędy sędziów i prokuratorów; itp.);

\section{Wstępne rekomendacje dotyczące miejsca pracy psychologa (por. pkt. 3.1 standardów ogólnych)}

- Osobny gabinet do przeprowadzania badania psychologicznego, spełniający następujące wymagania:

o zabezpieczony przed tym, aby ktoś wchodził w trakcie badania (np. odpowiednia wywieszka);

o usytuowany w pobliżu gabinetu medycznego, ponieważ osoba może wymagać natychmiastowej pomocy medycznej podczas wywiadu z psychologiem. Ew. w pobliżu pokoju innych pracowników socjalnych lub administracyjnych, którzy mogą udzielić wsparcia fizycznego (wezwanie pogotowia, pomoc w opanowaniu osoby);

o wyposażony w szafkę zamykaną na klucz oraz zaplombowaną, do której dostęp ma jedynie psycholog;

o wyposażony w telefon, komputer i drukarkę (pacjent otrzymuje opinię do ręki), stały dostęp do Internetu.

- W czasie kiedy psycholog nie pracuje w danym ośrodku, gabinet może być wykorzystywany przez inne osoby tylko i wyłącznie w sytuacjach awaryjnych. Inne osoby korzystające $\mathrm{z}$ gabinetu nie powinny mieć prawa ingerencji $\mathrm{w}$ jego wyposażenie, ani przechowywania w nim żadnych rzeczy.

\section{Wstępne rekomendacje dotyczące wymagań, jakie powinien spełniać zatrudniony psycholog}

- Wykształcenie wyższe na kierunku psychologia, specjalizacja psychologia kliniczna i/lub ukończone studia podyplomowe z zakresu psychoterapii;

- Obowiązkowe szkolenie z zakresu systemu pomocy osobom ubiegającym się o nadanie ochrony międzynarodowej $\mathrm{w}$ Polsce oraz $\mathrm{w}$ Europie $(\mathrm{m}$. in. ustawa $\mathrm{o}$ udzielaniu cudzoziemcom ochrony na terytorium RP, Procedura identyfikacji osób o 
szczególnych potrzebach wnioskujących o nadanie ochrony międzynarodowej w Polsce - perspektywa psychologiczna);

- Obowiązkowa znajomość języka kraju, z którego pochodzi najliczniejsza grupa osób ubiegających się o nadanie ochrony międzynarodowej (w Polsce jest to obecnie język rosyjski i angielski), płynnie w mowie;

- Wskazana znajomość innych języków, z których pochodzą osoby składające wnioski o nadanie ochrony międzynarodowej (np. francuskiego, arabskiego) płynnie w mowie;

- Obowiązkowe szkolenie z zakresu psychologii międzykulturowej;

- Obowiązkowe szkolenie z zakresu pracy psychologicznej z uchodźcami;

- Obowiązkowe szkolenie z zakresu pracy z thumaczem;

- Wskazane doświadczenie w pracy z cudzoziemcami.

\section{Wstępne rekomendacje dotyczące wymagań, jakie powinna spelniać osoba zatrudniona na stanowisku krajowego koordynatora psychologów pracujących w ośrodkach dla cudzoziemców:}

- Wykształcenie wyższe na kierunku psychologia, specjalizacja psychologia kliniczna i/lub ukończone studia podyplomowe z zakresu psychoterapii;

- Obowiązkowa znajomość systemu pomocy osobom ubiegającym się o nadanie ochrony międzynarodowej w Polsce oraz w Europie (m. in. ustawa o udzielaniu cudzoziemcom ochrony na terytorium RP, Procedura identyfikacji osób o szczególnych potrzebach wnioskujących o nadanie ochrony międzynarodowej w Polsce - perspektywa psychologiczna);

- Obowiązkowa znajomość języka kraju, z którego pochodzi najliczniejsza grupa osób ubiegających się o nadanie ochrony międzynarodowej (w Polsce jest to obecnie język rosyjski i angielski), płynnie w mowie;

- Wskazana znajomość innych języków z których pochodzą osoby składające wnioski o nadanie ochrony międzynarodowej (np. francuskiego, arabskiego) płynnie w mowie;

- Minimum pięcioletnie doświadczenie w pracy z osobami ubiegającymi się o nadanie ochrony międzynarodowej w Polsce;

- Minimum pięcioletnie doświadczenie w pracy psychologicznej w języku obcym;

- Minimum dwuletnie doświadczenie w pracy psychologicznej z udziałem thumacza. 